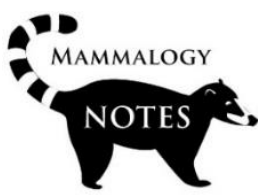

\title{
New Record of the Brown Sac-Wing Bat, Balantiopteryx infusca (Chiroptera, Emballonuridae) in Colombia
}

\author{
Jorge Horacio Velandia-Perilla1* (D), Adriana L. Guerrero-Chacón ${ }^{1,2}$ (D), \\ Adriana Ruiz-Espinosa $(+)^{1}$ iD
}

1 Universidad del Valle, Departamento de Biología, Grupo de Investigación en Ecofisiología, Biogeografía y Evolución. A.A. 25360. Cali, Colombia. 2 Department of Biology, University of Saskatchewan, Saskatoon, Saskatchewan, Canada, S7N 5E2

* Correspondence: jorgehvelandia@gmail.com

\begin{abstract}
Balantiopteryx infusca is a small bat endemic to southwestern Colombia and northwestern Ecuador. We present a new locality for $B$. infusca on the western slope of the Cordillera Occidental, Valle del Cauca, Colombia. The species is poorly known and there are scarce records of it in the country. This new record is noteworthy because it is the first one inside a National Natural Park for the country.
\end{abstract}

Keywords: Balantiopteryx infusca, PNN Farallones de Cali, southwestern Colombia.

\section{Resumen}

Balantiopteryx infusca es un murciélago pequeño endémico del suroeste de Colombia y el noroeste de Ecuador. Se presenta una nueva localidad para B. infusca en la vertiente occidental de la Cordillera Occidental, Valle del Cauca, Colombia. La especie es pobremente conocida y hay escasos registros de ésta en el país. Este nuevo registro es relevante porque es el primero en un Parque Nacional Natural para el país.

Palabras clave: Balantiopteryx infusca, PNN Farallones de Cali, suroeste de Colombia.

Species of the genus Balantiopteryx Peters, 1867 (Chiroptera: Emballonuridae) are easily distinguishable from other emballonurids by the anteriorly bulbous rostrum with lateral inflations extending forward over roots of the canines, premaxilla displaced laterally, no sagittal crest, and paraoccipital processes small, not projecting ventrally (Hood \& Gardner 2007). Balantiopteryx includes three species (Simmons \& Cirranello 2020): B. io Thomas, 1904, B. plicata Peters, 1867, and B. infusca (Thomas, 1897), of which the latter is characterized by its medium size among the three species of the genus, length of forearm 37.5 to $40.5 \mathrm{~mm}$, inner margin of ear slightly concave, braincase posteriorly elongate, moderate frontal depression, rostrum inflated both anteriorly and posteriorly, and narrow 
mesopterygoid fossa. Moreover, the geographic ranges of Balantioperyx species do not overlap (Hill 1987; Arroyo-Cabrales \& Jones 1988).

Balantiopteryx infusca is restricted to the rainforest of northwestern Ecuador, and southwestern Colombia, where it has been reported from two localities in Ecuador (Romero et al. 2018) and four localities in Colombia at elevations between 393 and $1200 \mathrm{~m}$ above sea level (Mantilla-Meluk et al. 2014, Castaño-Salazar \& Cárdenas Mosquera 2020). The species is listed as Vulnerable (VU) by the IUCN (Tirira 2015) due to continuous human activity (logging). So far, it is unknown whether the species occurs in national protected areas within its distribution range in Colombia (Castaño-Salazar \& Cárdenas-Mosquera 2020). Here, we present a new locality record of B. infusca in the Valle del Cauca, which represents the first record within a national protected area for Colombia.

On 21st and 22nd January 2010 we visited two artificial tunnels in the daylight hours:

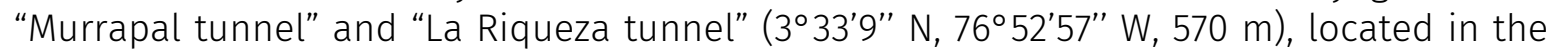
"Alto Anchicayá" area, the boundary between Dagua and Buenaventura municipalities, "Parque Nacional Natural Farallones de Cali", in the western slope of the Cordillera Occidental, Valle del Cauca Department. The tunnels were built in the 1970s when a dam started to operate, however, they are no longer used. In these tunnels, groups of 20-30 individuals were perched at a height of about 3-4 m, about $10 \mathrm{~m}$ from the main entrance of the tunnels. Mist nets were placed at the entrance of the tunnels between 17:30 and 23:30 h, and five individuals of B. infusca were captured, three in "Murrapal" and two in "La Riqueza" (Figure 1). The specimens were collected under the permit of Parques Nacionales Naturales de Colombia (Permit number PIDB DTPA 002-11) and housed in the mammal collection of the Universidad del Valle, Cali, Colombia.
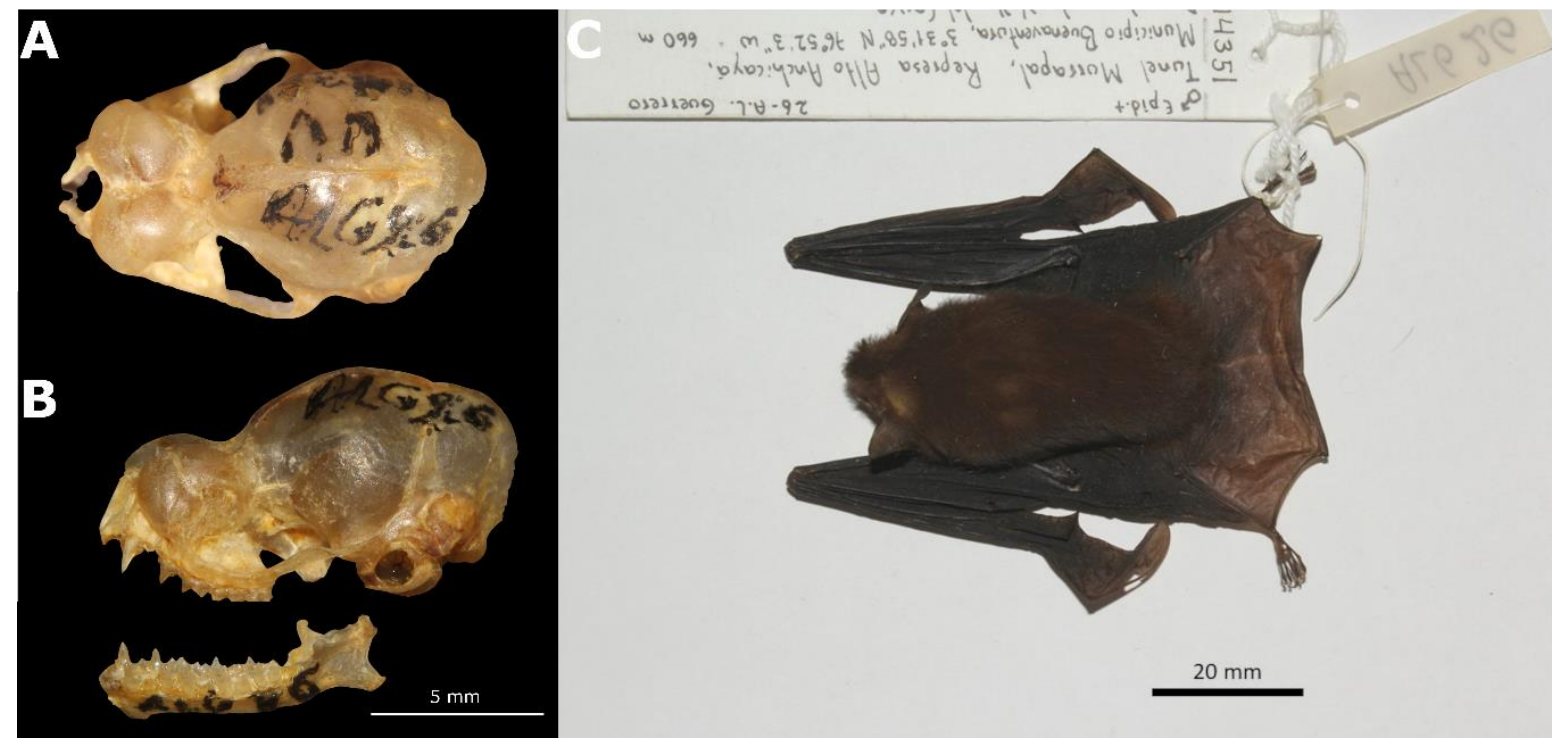

FIGURE 1. Dorsal(A) and lateral(B) views of the skull, and dorsal view of the skin (C) of Balantiopteryx infusca (UV 14351) collected at "Parque Nacional Natural Farallones de Cali" in Colombia (Photos by E.A. Soto).

All specimens had their skulls extracted for examination. External and craniodental measurements were taken using a digital caliper to the nearest $0.1 \mathrm{~mm}$ (McCarthy et al. (2000); specimen UV-14348's skull was fractured thus cranial measurements could not be taken (Table 1). The external and craniodental measurements of our specimens are within 
the ranges reported previously for the species (Arroyo-Cabrales \& Jones 1988, McCarthy et al. 2000). The reproductive activity was documented by examining females' mammary glands and abdominal palpation, whereas in males it was observed whether the testicles had descended to the scrotum or not (Racey 1982). The individuals exhibited the typical coloration of the species, dark brown dorsal fur with a light banding pattern exhibiting darker tips, a middle band less dark, and bases pale brown whereas the ventral hair was lighter; the membranes were black and presented some hair on the dorsal surface of the uropatagium.

TABLE 1. Craniodental and body measurements $(\mathrm{mm})$ of the five specimens of Balantiopteryx infusca collected at "Parque Nacional Natural Farallones de Cali" in Colombia.

\begin{tabular}{|c|c|c|c|c|c|c|c|}
\hline \multirow{2}{*}{$\begin{array}{l}\text { Measurement } \\
\text { type }\end{array}$} & \multirow[t]{2}{*}{ Characters } & \multirow[t]{2}{*}{ Description } & \multicolumn{5}{|c|}{ Specimens } \\
\hline & & & $\begin{array}{c}\text { UV } \\
14348 \\
\end{array}$ & $\begin{array}{c}\text { UV } \\
14349\end{array}$ & $\begin{array}{c}\text { UV } \\
14351\end{array}$ & $\begin{array}{c}\text { UV } \\
14386 \\
\end{array}$ & $\begin{array}{c}\text { UV } \\
14387 \\
\end{array}$ \\
\hline Cranial & GLS & Greatest skull length & - & 13.41 & 12.57 & 13.30 & 14.07 \\
\hline Cranial & $\mathrm{CON} \mathrm{INCl}$ & Condyloincisive length & - & 11.10 & 11.70 & 11.51 & 13.83 \\
\hline Cranial & ROST LEN & Rostral length & - & 2.31 & 2.50 & 3.97 & 3.53 \\
\hline Cranial & PALATE & Palatal length & - & 3.83 & 3.83 & 5.40 & 5.93 \\
\hline Cranial & ZYGO BR & $\begin{array}{l}\text { Width taken across zygomatic } \\
\text { arches at the widest point } \\
\text { near the posterior junction } \\
\text { with the braincase }\end{array}$ & - & 8.30 & 8.20 & 8.67 & 8.57 \\
\hline Corporal & HB & Length head and body & 47.00 & 48.00 & 43.00 & 43.00 & 49.00 \\
\hline Corporal & TAIL & Tail length & 16.00 & 17.00 & 17.00 & 13.00 & 14.00 \\
\hline Corporal & EAR & Ear length & 12.00 & 11.00 & 12.00 & 13.00 & 11.00 \\
\hline Corporal & $\mathrm{HF}$ & Hindfoot & 8.00 & 7.00 & 7.00 & 7.00 & 7.00 \\
\hline Corporal & TIBIA & Tibia & 14.27 & 14.53 & 13.85 & 14.75 & 14.41 \\
\hline Corporal & FA & Forearm & 38.77 & 41.24 & 39.20 & 41.48 & 41.70 \\
\hline
\end{tabular}

The locality where we collected these specimens is within a protected area that encompasses 15,000 ha of different ecological zones including Tropical rainforest, Subtropical cloud forest, and Paramo. In particular, the "Anchicayá" area is on the western slope of the Andes with elevations between 5000-1200 m asl, relative humidity of 85\%, rainfall 3,000 $\mathrm{mm}$, and mainly covered by native forest. Logging and deforestation are the main threats to biodiversity within the zone due to illicit crops and expansion of the agricultural frontier added to illegal mining (UAESPNN 2005; PMSC 2013). Nevertheless, the areas subjacent to our occurrence record are well preserved as they are part of the buffer zone of the "Alto Anchicaya Dam" and are regularly patrolled by security personnel from the Pacific Energy Company - EPSA which limits human activity within the area. The closest human settlement to the sampled tunnels is "Corregimiento El Queremal" located about $20 \mathrm{Km}$ east of the locality.

Balantiopteryx infusca is a rare species with few locality records, and in Colombia has been scarcely recorded in the last decades (Castaño-Salazar \& Cárdenas-Mosquera 2020). The species is threatened due to deforestation, and a resulting reduction of available habitat (Tirira 2015) which makes our discovery remarkable given that the populations of $B$. infusca in this locality are presumably not very exposed to habitat loss and human activity, being this the first country record of the species in a national protected area. However, populational assessments and natural history studies are needed to evaluate the current state of the populations in this area and determine the existing threats that this species is facing both within and outside protected areas. 
In particular, the few occurrences of the species suggest that it prefers wet cave-like habitats as roosts (McCarthy et al. 2000). Therefore, an initial step could be to evaluate the availability of these roost types within the potential habitat areas of the species. In any case, recent records of the species, such as ours and Castaño-Salazar \& CárdenasMosquera (2020), are noteworthy because they extend the distribution of the species and confirm that $B$. infusca still occurs in the forests of the Chocó region (Figure 2).

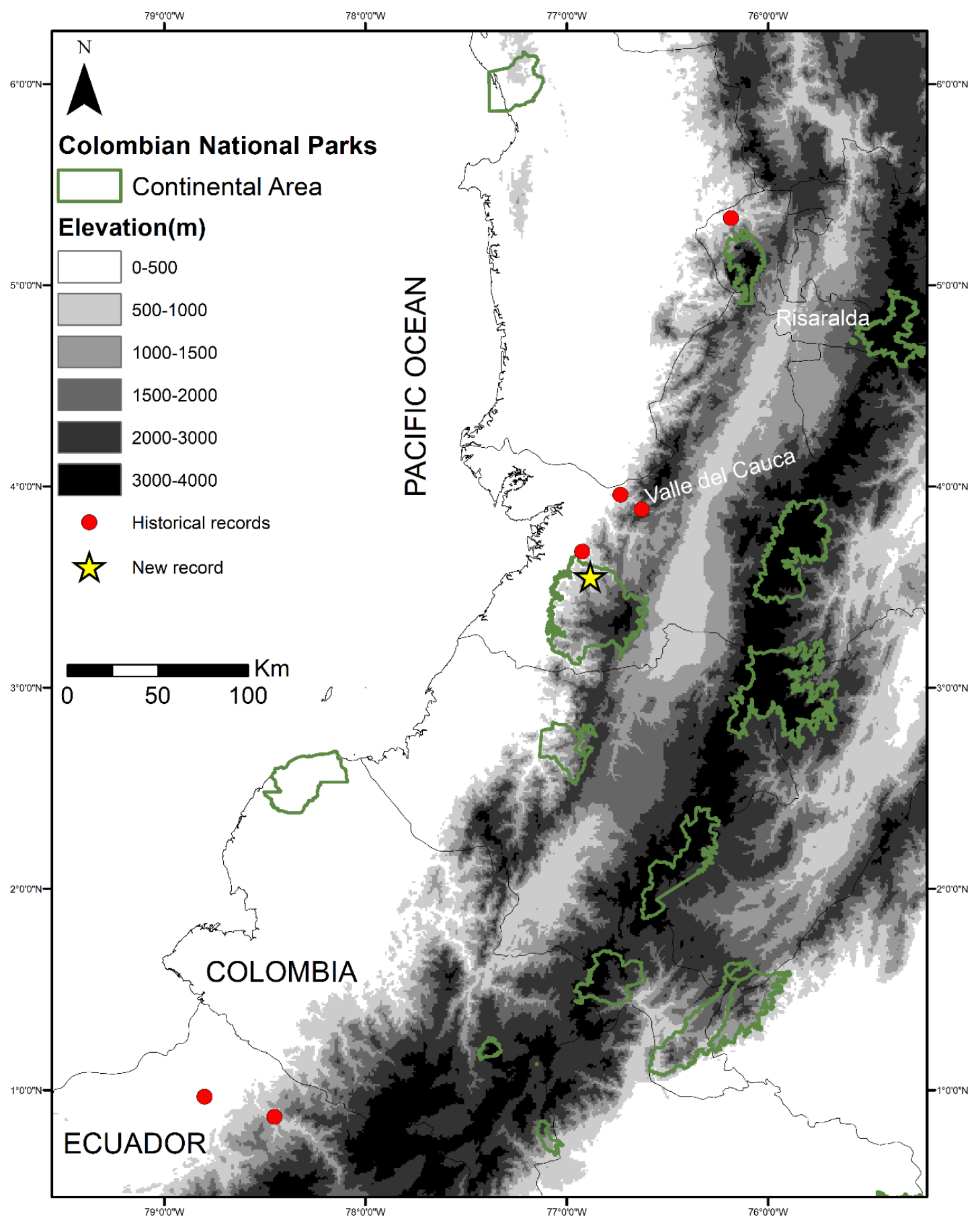

FIGURE 2. Map of western Colombia and northwest Ecuador, showing locality records for Balantioperyx infusca. New locality (yellow star) and historical locations (red dots). 
The relatively few records of $B$. infusca may be due to the difficulty of capturing them by conventional methods. Most existing specimens have been collected directly from their shelters, although its detectability could be improved by using alternative methods like acoustic monitoring. There has also been a paucity of sampling overtime at locations within the species' known range which highlights the importance of conducting further research to establish the species' actual distribution. The discovery of colonies of this and other species provides an opportunity for further studies to understand different aspects of the biology and natural history of the region's chiropterofauna, so far poorly known, and within a region that is threatened by the rapid intervention of their natural habitats. Thus, it is imperative to improve our knowledge about the population status and geographic distribution of this species, to assure the occurrences of viable populations within natural protected areas.

\section{ACKNOWLEDGMENTS}

We thank the Administrative Department of Science, Technology and Innovation (COLCIENCIAS) for funding this study as part of the project "Efecto de la temperatura ambiental sobre los patrones de distribución de pequeños mamíferos frente a un escenario de cambio climático" (Project number: 110645221235). The Pacific Power Company (EPSA) assisted with logistics during fieldwork. Edier Alberto Soto took pictures of the skull. Timothy Paul Cutajar corrected the English manuscript. Vladimir Rojas-Díaz confirmed the identification of specimens. Sergio Solari and two anonymous reviewers made comments that improved this manuscript.

\section{REFERENCES}

Arroyo-Cabrales J, Jones K Jr. 1988. Balantiopteryx io and Balantiopteryx infusca. Mammalian Species 313: 1-3. https:// doi.org/10.2307/3504205

Castaño-Salazar JH, Cardenas-Mosquera BA. 2020. New distribution record of the brown sac-wing bat Balantiopteryx infusca in Colombia. Therya Notes 1(1): 82-85. https:// doi.org/10.12933/therya_notes-20-18

Emmons LH, Feer F. 1990. Neotropical rain forest mammals. The University of Chicago Press. Chicago.

Hill JE. 1987. A note on Balantiopteryx infusca (Thomas, 1897) (Chiroptera: Emballonuridae). Mammalia 50(4): 558-560.

Hood C, Gardner AL. 2007. Family Emballonuridae. In: Gardner AL, editor. Mammals of South America: Marsupials, Xenarthrans, Shrews, and Bats. Chicago, ILL, USA: The University of Chicago Press. p. 188-207.

Mantilla-Meluk H, Ramírez-Chaves HE, Jiménez-Ortega AM, Rodríguez-Posada ME. 2014. Emballonurid bats from Colombia: Annotated checklist, distribution, and biogeography. Therya 5:229-255. https:// doi.org/10.12933/therya-14-189

McCarthy TJ, Albuja L, Manzano I. 2000. Rediscovery of the brown sac-winged bat, Balantiopteryx infusca (Thomas, 1897), in Ecuador. Journal of Mammalogy 81(4): 958-961. https:// doi.org/10.1644/1545-1542(2000)081\%3C0958:ROTBSW\%3E2.0.CO;2

Personeria Municipal Santiago de Cali - PMSC. 2013. Informe situacional PNN Farallones de Cali. Cali, Colombia $\quad 46 \quad$ pp. https://www.parquesnacionales.gov.co/portal/wpcontent/uploads/2013/12/informe-farallones.pdf. Accessed on 18 January 2021

Racey PA. 1982. Ecology of Bat Reproduction. In: Kunz TH, editor. Ecology of Bats. Boston, MA, USA: Springer. p. 57-104. 
Romero V, Vallejo AF, Boada C 2018. Balantiopteryx infusca. In: Brito J, Camacho MA, Romero V, Vallejo AF, editors. Mamíferos del Ecuador. Version 2018.0. Museo de Zoología, Pontificia Universidad Católica del Ecuador. https:/ / bioweb.bio/faunaweb/mammaliaweb/FichaEspecie/Balantiopteryx\%20infusca. Accessed on October 26, 2020 November 2020.

Simmons NB, Cirranello AL. 2020. Bat Species of the World: A taxonomic and geographic database. https:// batnames.org/. Accessed on 6 November 2020.

Tirira D. 2015. Balantiopteryx infusca (errata version published in 2016). The IUCN Red List of Threatened Species 2015: e.T2531A97206692.

https:// dx.doi.org/10.2305/IUCN.UK.2015-4.RLTS.T2531A22029804.en. Accessed on 6 July 2020.

Unidad Administrativa Especial del Sistema de Parques Nacionales Naturales - UAESPNN. 2005. Plan de Manejo 2005-2009 Parque Nacional Natural Farallones de Cali. Cali, Colombia 338 pp.

https:/ / www.parquesnacionales.gov.co/portal/wpcontent/uploads/2013/12/PlandeManejoFarallonesdeCali.pdf. Accessed on 18 January, 2021

Editora: Aída Otálora-Ardila Recibido: 2020-11-08

Revisado: 2021-01-20

Aceptado: 2021-05-04

Publicado: 2021-05-24 